\title{
Inclusion of glycerol in forage diets increases methane production in a rumen simulation technique system
}

\author{
Jorge Avila-Stagno ${ }^{1,2,3}$, Alexandre V. Chaves ${ }^{1 *}$, Gabriel O. Ribeiro Jr ${ }^{2,4}$, Emilio M. Ungerfeld ${ }^{5}$ \\ and Tim A. McAllister ${ }^{2}$ \\ ${ }^{1}$ Faculty of Veterinary Science, University of Sydney, Sydney, NSW 2006, Australia \\ ${ }^{2}$ Lethbridge Research Centre, Agriculture and Agri-Food Canada, Lethbridge, Alberta, Canada T1J 4B1 \\ ${ }^{3}$ Facultad de Ciencias Veterinarias, Universidad de Concepción, Chillan, Chile \\ ${ }^{4}$ Escola de Veterinaria, Universidade Federal de Minas Gerais, Belo Horizonte, MG 30123-970, Brazil \\ ${ }^{5}$ Centro de Investigación y Desarrollo CIEN Austral CONICYT Regional R10C1002, Puerto Montt, Chile \\ (Submitted 15 March 2013 - Final revision received 28 August 2013 - Accepted 29 August 2013 - First published online 7 October 2013)
}

\section{Abstract}

We hypothesised that the inclusion of glycerol in the forage diets of ruminants would increase the proportion of propionate produced and thereby decrease in vitro $\mathrm{CH}_{4}$ production. This hypothesis was examined in the present study using a semi-continuous fermentation system (rumen simulation technique) fed a brome hay $(8.5 \mathrm{~g})$ and maize silage $(1.5 \mathrm{~g})$ diet with increasing concentrations $(0,50,100 \mathrm{and} 150 \mathrm{~g} / \mathrm{kg}$ $\mathrm{DM})$ of glycerol substituted for maize silage. Glycerol linearly increased total volatile fatty acids production $(P<0 \cdot 001)$. Acetate production was quadratically affected $(P=0.023)$ and propionate and butyrate production was linearly increased $(P<0 \cdot 001)$. Glycerol linearly increased $(P=0.011)$ DM disappearance from hay and silage. Crude protein disappearance from hay was not affected $(P=0 \cdot 789)$, but that from silage was linearly increased $(P<0 \cdot 001)$ with increasing glycerol concentrations. Neutral-detergent fibre $(P=0 \cdot 040)$ and aciddetergent fibre $(P=0.031)$ disappearance from hay and silage was linearly increased by glycerol. Total gas production tended to increase linearly $(P=0.061)$ and $\mathrm{CH}_{4}$ concentration in gas was linearly increased $(P<0 \cdot 001)$ by glycerol, resulting in a linear increase $(P<0 \cdot 001)$ in $\mathrm{mg} \mathrm{CH} / \mathrm{g} \mathrm{DM}$ digested. Our hypothesis was rejected as increasing concentrations of glycerol in a forage diet linearly increased $\mathrm{CH}_{4}$ production in semi-continuous fermenters, despite the increases in the concentrations of propionate. In conclusion, this apparent discrepancy is due to the more reduced state of glycerol when compared with carbohydrates, which implies that there is no net incorporation of electrons when glycerol is metabolised to propionate.

Key words: In vitro techniques: Biodiesel by-products: Hydrogen sink: Methane

Glycerol has been used as a feed ingredient to replace grain in dairy ${ }^{(1)}$ and finishing beef cattle diets ${ }^{(2,3)}$ and in growing-finishing lamb diets ${ }^{(4)}$. Results suggest that glycerol at $50-100 \mathrm{~g} / \mathrm{kg}$ DM does not affect weight gain and may improve feed conversion when substituted for barley or maize grain in beef cattle diets ${ }^{(3)}$. However, a greater concentration $(>120 \mathrm{~g} / \mathrm{kg}$ diet DM) of glycerol has been reported to result in reduced intakes in cattle ${ }^{(2,3)}$ and sheep ${ }^{(4-6)}$ fed high-grain diets.

Glycerol can increase blood glucose levels in cattle and sheep by being directly absorbed through the rumen wall and converted to glucose in the liver ${ }^{(7)}$ or by being fermented in the rumen mainly to propionate, which in turn can be absorbed and converted to glucose in the liver ${ }^{(1,8)}$. The replacement of wheat $\operatorname{starch}^{(9)}$ or barley grain ${ }^{(10)}$ with glycerol has been reported to linearly increase propionic acid production and reduce the acetate:propionate ratio in vitro. Shifts towards propionate fermentation have been suggested as a means of reducing $\mathrm{CH}_{4}$ emissions, since the metabolic pathways leading to propionate have been proposed as a hydrogen sink ${ }^{(11-13)}$.

Previous studies have reported increases in propionate production with only a numerical decrease of $\mathrm{CH}_{4}$ in vitro ${ }^{(10)}\left(\mathrm{mg} \mathrm{CH}_{4} / \mathrm{g}\right.$ DM incubated and $\mathrm{mg} \mathrm{CH}_{4} / \mathrm{g} \mathrm{DM}$ digested) and in vivo ${ }^{(4)}\left(\mathrm{g} \mathrm{CH}_{4} / \mathrm{lamb}\right.$ per $\mathrm{d}, \mathrm{g} \mathrm{CH}_{4} / \mathrm{kg}$ DM intake, $\mathrm{g} \mathrm{CH}_{4} / \mathrm{kg}$ DM digested, percentage of gross and digestible energy intake lost as $\mathrm{CH}_{4}$ ) when glycerol replaced barley grain in finishing lamb diets. A possible cause for this lack of effect is that the shift to propionate fermentation may be of relatively low magnitude given the propiogenic

Abbreviations: ADF, acid-detergent fibre; NDF, neutral-detergent fibre; RUSITEC, rumen simulation technique; VFA, volatile fatty acid.

*Corresponding author: A. V. Chaves, fax +61293513957, email alex.chaves@sydney.edu.au 
properties of high-starch diets. The findings reported by Rémond et $a l .{ }^{(7)}$ support this concept, as propiogenesis has been shown to substantially increase when glycerol is added to high-fibre diets than when added to high-starch diets incubated in vitro. $\mathrm{CH}_{4}$ production ( $\mathrm{ml} \mathrm{CH}_{4} / \mathrm{g} \mathrm{DM}$ incubated) in $24 \mathrm{~h}$ in vitro batch cultures has been reported to decrease when glycerol is added to alfalfa- or maize grain-based diets $^{(14)}$. Since the acetate:propionate ratio is progressively reduced over a period of 3-4 d after glycerol supplementation in cattle ${ }^{(7,15)}$, it is probable that enteric $\mathrm{CH}_{4}$ production may decrease as rumen microbial populations adapt to the inclusion of glycerol in the diet.

As feeding of forage to breeding and growing herds in the beef cattle industry accounts for more than $80 \%$ of greenhouse gas emissions and $55 \%$ of $\mathrm{CH}_{4}$ emissions ${ }^{(16)}$, inclusion of glycerol in forage diets is likely to have a greater impact on the reduction of greenhouse gases emitted by beef cattle. We hypothesised that the inclusion of glycerol up to $150 \mathrm{~g} / \mathrm{kg}$ in forage-based diets may decrease $\mathrm{CH}_{4}$ production in a semicontinuous fermentation system (RUSITEC, rumen simulation technique). Thus, the objective of the present study was to evaluate the effects of adding glycerol to a forage diet in a semi-continuous fermentation apparatus (RUSITEC) on fermentation variables, including $\mathrm{CH}_{4}$ production.

\section{Experimental methods}

The present experiment was conducted at the Agriculture and Agri-Food Canada Research Centre in Lethbridge, Alberta, Canada. Donor cows used in the experiment were cared for in accordance with the guidelines of the Canadian Council on Animal Care ${ }^{(17)}$.

\section{Experimental design and treatments}

The experiment was a complete randomised design with four dietary treatments replicated in two RUSITEC apparatuses ${ }^{(18)}$. The duration of the experiment was $15 \mathrm{~d}$. The first $8 \mathrm{~d}$ were used for adaptation, followed by $7 \mathrm{~d}$ of sampling (day 9 to day 15). The experimental treatments included brome hay, maize silage and glycerol in the following proportions: (1) $8.5 \mathrm{~g}$ hay $+1.5 \mathrm{~g}$ maize silage (control); (2) $8.5 \mathrm{~g}$ hay $+1.0 \mathrm{~g}$ maize silage $+0.5 \mathrm{~g}$ glycerol; (3) $8.5 \mathrm{~g}$ hay $+0.5 \mathrm{~g}$ maize silage $+1.0 \mathrm{~g}$ glycerol; (4) $8.5 \mathrm{~g}$ hay $+1.5 \mathrm{~g}$ glycerol. These amounts were selected to test inclusions of $50-150 \mathrm{~g} / \mathrm{kg}$ based on previous in vivo results ${ }^{(4)}$, which indicated DM intake reductions at glycerol concentrations exceeding $140 \mathrm{~g} / \mathrm{kg}$.

The ingredients and chemical composition of the substrates are reported in Table 1. Hay and silage were ground through a $4 \mathrm{~mm}$ screen (Arthur Thomas Company). Glycerol (99.5\% pure, Sigma-Aldrich) was thoroughly mixed with the hay portion of the diet for each treatment before filling the polyester bags $(100 \times 200 \mathrm{~mm}$; pore size $=50 \mu \mathrm{m}$; B. \& S.H. Thompson). Maize silage was incubated in separate bags $(50 \times 100 \mathrm{~mm}$; pore size $=50 \mu \mathrm{m})$.
Table 1. Chemical composition of the substrates

\begin{tabular}{lcc}
\hline & $\begin{array}{c}\text { Brome hay } \\
\text { (g/kg DM) }\end{array}$ & $\begin{array}{c}\text { Maize silage } \\
\text { (g/kg DM) }\end{array}$ \\
\hline DM & 953 & 982 \\
Organic matter & 909 & 930 \\
Neutral-detergent fibre & 683 & 459 \\
Acid-detergent fibre & 485 & 346 \\
Crude protein & 87.5 & $86 \cdot 3$ \\
Crude fat & 24 & 26 \\
Ash & 91 & 70 \\
Non-fibrous carbohydrates* & 115 & 359 \\
\hline
\end{tabular}

${ }^{\star}$ Calculated as $1000-$ (crude protein + neutral-detergent fibre + crude fat + ash).

\section{Experimental apparatuses and incubations}

Each RUSITEC apparatus was equipped with eight $920 \mathrm{ml}$ volume anaerobic fermenters. Each fermenter had an inlet for the infusion of buffer and an effluent output port. The fermenters were immersed in a water-bath maintained at $39^{\circ} \mathrm{C}$. The four dietary treatments were randomly assigned to duplicate fermenters within each RUSITEC apparatus (four replications per treatment). The experiment was started by filling each fermentation vessel with $180 \mathrm{ml}$ of warmed McDougall's buffer ${ }^{(19)}$ modified to contain $1.0 \mathrm{~g} / 1$ of $\left(\mathrm{NH}_{4}\right)_{2} \mathrm{SO}_{4}, 720 \mathrm{ml}$ of strained rumen fluid, one bag containing $20 \mathrm{~g}$ of wet solid rumen digesta and two additional bags containing the dietary ingredients as described above. After $24 \mathrm{~h}$, the solid rumen digesta bag was replaced with two bags containing each feed. Thereafter, bags that had been incubated for $48 \mathrm{~h}$ were replaced daily. Artificial saliva was continuously infused into the fermenters at a dilution rate of $2 \cdot 9 \% / \mathrm{h}$. During nylon bag exchange, each fermentation vessel was flushed with $\mathrm{O}_{2}$-free $\mathrm{CO}_{2}$ to maintain anaerobic conditions. Effluent accumulation was measured daily during feed bag exchange and collected in a 2.0 litres container containing sodium azide $(1 \mathrm{~g} / \mathrm{l})$ to arrest microbial growth.

Inoculum was obtained $2 \mathrm{~h}$ after feeding from two ruminally cannulated cows fed a forage diet containing barley silage, barley grain and a mineral vitamin supplement (71:25:4 DM basis). Rumen fluid was collected, pooled and filtered through four layers of cheesecloth into an insulated thermos and transported immediately to the laboratory. Approximately $400 \mathrm{~g}$ of ruminal solid digesta were also collected for the initial inoculation of the fermenters. Fermentation was initiated in the RUSITEC apparatuses on two consecutive days (two runs).

\section{Sample collection}

DM disappearance. DM disappearance at $48 \mathrm{~h}$ was determined daily from day 9 to day 15 . Feed bags were removed from each fermenter, washed in cold, running distilled water until water was clear, and dried at $55^{\circ} \mathrm{C}$ for $48 \mathrm{~h}$. To ensure that there was sufficient sample for analysis, silage and concentrate bag residues were pooled over 2 and $3 \mathrm{~d}$, respectively. Samples were ground through a $1 \mathrm{~mm}$ screen in a Wiley mill (standard model 4; Arthur H. Thomas) before chemical analysis. 


\section{Fermentation metabolites}

Fermentation gas was collected into reusable 2-litre vinyl urine collection bags (Bard, Inc.) attached to each fermenter. Just before feed bag exchange, daily total gas production from each fermenter was determined by water displacement ${ }^{(20)}$. From day 9 to day 15, just before the determination of total gas, gas samples were collected from the septum of the collection bags using a twenty-six-gauge needle (Becton Dickinson). Samples $(20 \mathrm{ml})$ were transferred to evacuated $6.8 \mathrm{ml}$ exetainers (Labco Limited) for immediate analysis of $\mathrm{CH}_{4}$. Fermenter $\mathrm{pH}$ was recorded (Orion model 260A, Fisher Scientific) daily at the time of feed bag exchange. To determine the concentration of volatile fatty acids (VFA), subsamples of fermenter liquid $(4.0 \mathrm{ml})$ were collected directly from the fermentation vessels ${ }^{(19)}$ at the time of feed bag exchange and placed in screw-capped vials preserved with $400 \mu \mathrm{l}$ of $25 \%$ $(\mathrm{w} / \mathrm{w})$ metaphosphoric acid and immediately frozen at $-20^{\circ} \mathrm{C}$ until analysis. At the same time, $4.0 \mathrm{ml}$ subsamples of fermenter fluid were also collected, placed in screw-capped vials and preserved with $400 \mu \mathrm{l}$ of TCA until the determination of the concentration of $\mathrm{NH}_{3}-\mathrm{N}$. The concentrations of VFA and $\mathrm{NH}_{3}-\mathrm{N}(\mathrm{mmol} / \mathrm{l})$ were multiplied by the outflow rate of fluid infused to the vessels (litres/d) to determine VFA and $\mathrm{NH}_{3}-\mathrm{N}$ production $(\mathrm{mmol} / \mathrm{d})$.

\section{Chemical analysis}

Subsamples of each treatment were used for chemical analysis. Feed and fermentation residues were analysed for DM content (method no. 930.15) $)^{(21)}$ and ash (method no. 942.05) ${ }^{(21)}$. The concentration of neutral-detergent fibre (NDF) was determined and expressed inclusive of residual $\mathrm{ash}^{(22)}$. The concentration of acid-detergent fibre (ADF) was determined according to the method 973.18 (Association of Official Analytical Chemists) ${ }^{(21)}$. The concentration of total N (method no. 990.03) (21) $^{\text {was }}$ determined using a mass spectrometer (NA 1500, Carlo Erba Instruments) ${ }^{(23)}$. The concentration of crude fat was determined by diethyl ether extraction (Association of Official Analytical Chemists ${ }^{(21)}$, method 920.39) using the Goldfisch Fat Extractor (Labconco Corporation). The concentrations of VFA and $\mathrm{NH}_{3}-\mathrm{N}$ in the liquid effluent were determined by $\mathrm{GC}^{(23)}$ and the modified Berthelot method ${ }^{(24)}$, respectively. The concentration of $\mathrm{CH}_{4}$ in the gas samples was determined using a Varian gas chromatograph equipped with GS-CarbonPLOT $30 \mathrm{~m} \times 0.32 \mathrm{~mm} \times 3 \mu \mathrm{m}$ column and thermal conductivity detector (Agilent Technologies Canada, Inc.). Oven temperature was $35^{\circ} \mathrm{C}$ (isothermal). The carrier gas was helium $(27 \mathrm{~cm} / \mathrm{s})$, the injector temperature was $185^{\circ} \mathrm{C}(1: 30$ split, $250 \mu \mathrm{l}$ injector volume), and the detector temperature was $150^{\circ} \mathrm{C}$ (thermal conductivity detector).

\section{Statistical analysis}

Data were analysed using the MIXED procedure of SAS (SAS, Inc., 2013; SAS Online Doc 9.1.3).

The model included the fixed effects of treatment (substrate), day and treatment $\times$ day interactions with the day of sampling from each fermenter treated as a repeated measure. Therefore, the individual fermenter was used as the experimental unit for statistical analysis. The minimum values of Akaike's information criterion were used to select the covariance structure among compound symmetry, heterogeneous compound symmetry, autoregressive, heterogeneous autoregressive, Toeplitz, unstructured and banded for each parameter. Orthogonal polynomial contrasts were carried out to test for linear, quadratic and cubic responses to increasing concentrations of glycerol $(0,50,100$ and $150 \mathrm{~g} / \mathrm{kg}$ $\mathrm{DM})$ in the substrate. Significance was declared at $P \leq 0.05$, and a trend was discussed when $0.05<P<0 \cdot 10$.

\section{Results}

\section{Effects of glycerol on nutrient disappearance}

Increasing concentrations of glycerol resulted in a linear increase in DM disappearance from hay $(P=0.001)$ and maize silage $(P=0 \cdot 011$; Table 2$)$. Crude protein disappearance from hay was not affected $(P=0.788)$, but that from silage was linearly increased $(P<0 \cdot 001)$. Glycerol linearly increased $\operatorname{NDF}(P=0.040)$ and $\operatorname{ADF}(P=0.031)$ disappearance from hay and silage.

\section{Effects of glycerol on fermentation}

There were no interactions between treatments and sampling day for any of the fermentation variables. The inclusion of glycerol linearly decreased culture $\mathrm{pH}(P=0.035)$ and increased total VFA production $(P<0 \cdot 001$; Table 3$)$. A quadratic effect $(P=0.023)$ for acetate production was detected with increasing concentrations of glycerol, whereas propionate production was linearly increased $(P<0 \cdot 001)$, resulting in a linear and quadratic decline $(P<0.001)$ in the acetate:propionate ratio. Increasing concentrations of glycerol also resulted in a linear increase in butyrate $(P<0 \cdot 001)$ and valerate $(P<0.001)$ production. The concentration of $\mathrm{NH}_{3}$ was linearly reduced by the addition of glycerol $(P<0 \cdot 001)$, although the magnitude of the effect was small.

With increasing concentrations of glycerol in the substrate, $24 \mathrm{~h}$ cumulative gas production tended to increase linearly $\left(P=0 \cdot 061\right.$; Table 4) and $\mathrm{CH}_{4}$ concentration in gas was linearly increased $(P<0 \cdot 001)$. This resulted in a linear increase in $\mathrm{CH}_{4}$ production when expressed as total $\mathrm{mg} \mathrm{CH}_{4} / \mathrm{d}, \mathrm{mg} \mathrm{CH}_{4} / \mathrm{g}$ total DM incubated $(P=0.001)$ and $\mathrm{mg} \mathrm{CH}_{4} / \mathrm{g}$ of hay $\mathrm{DM}$ disappeared $(P<0 \cdot 001)$.

\section{Discussion}

The effects of glycerol on fibre digestion have been variable. The linear increase in DM, NDF and ADF loss from hay and silage is in agreement with the findings of the study of Wang et $a l .{ }^{(25)}$, who reported increased in sacco effective degradability of DM and NDF from forage as well as an improved digestibility of total tract nutrients, including NDF, when steers were fed increasing concentrations of glycerol $(0,11,22$ and $33 \mathrm{~g} / \mathrm{kg} \mathrm{DM})$ in mixed diets $(600 \mathrm{~g} / \mathrm{kg}$ maize 
Table 2. Effects of increasing concentrations of glycerol on the disappearance of DM, crude protein (CP), neutral-detergent fibre (NDF) and acid-detergent fibre (ADF) of brome hay and maize silage in the rumen simulation technique

(Mean values with their standard errors)

\begin{tabular}{|c|c|c|c|c|c|c|c|c|}
\hline \multirow[b]{2}{*}{ Items } & \multicolumn{4}{|c|}{ Glycerol* $(g / k g)$} & \multirow[b]{2}{*}{ SEM } & \multicolumn{3}{|c|}{$P$} \\
\hline & 0 & 50 & 100 & 150 & & Linear & Quadratic & Cubict \\
\hline \multicolumn{9}{|c|}{ DM loss (mg/g) } \\
\hline Hay & 382 & 377 & 386 & 405 & $4 \cdot 1$ & 0.001 & 0.005 & NS \\
\hline Silage & 510 & 523 & 562 & - & $13 \cdot 7$ & 0.011 & NS & - \\
\hline Total DM & 402 & 424 & 461 & 501 & $3 \cdot 7$ & $<0.001$ & 0.008 & NS \\
\hline \multicolumn{9}{|c|}{ CP loss (mg/g) } \\
\hline Hay & 622 & 624 & 642 & 633 & $15 \cdot 5$ & NS & NS & NS \\
\hline Silage & 633 & 674 & 706 & - & $9 \cdot 7$ & $<0.001$ & NS & - \\
\hline \multicolumn{9}{|c|}{ NDF loss (mg/g) } \\
\hline Hay & 213 & 224 & 221 & 245 & $10 \cdot 7$ & 0.040 & NS & NS \\
\hline Silage & 83 & 119 & 157 & - & $14 \cdot 4$ & $<0.001$ & NS & - \\
\hline \multicolumn{9}{|c|}{ ADF loss (mg/g) } \\
\hline Hay & $67 \cdot 8$ & $79 \cdot 3$ & $79 \cdot 1$ & $113 \cdot 0$ & 9.62 & 0.031 & NS & NS \\
\hline Silage & $26 \cdot 2$ & 23.5 & 67.4 & - & $3 \cdot 26$ & $<0.001$ & $<0.001$ & - \\
\hline
\end{tabular}

* Experimental substrates: $0=8.5 \mathrm{~g}$ brome hay $+1.5 \mathrm{~g}$ maize silage; $50=8.5 \mathrm{~g}$ brome hay $+1.0 \mathrm{~g}$ maize silage $+0.5 \mathrm{~g}$ glycerol; $100=8.5 \mathrm{~g}$ hay $+0.5 \mathrm{~g}$ maize silage $+1.0 \mathrm{~g}$ glycerol; $150=8.5 \mathrm{~g}$ hay $+1.5 \mathrm{~g}$ glycerol.

† Cubic contrasts for silage disappearance cannot be calculated since there were only three levels of silage in diet DM.

stover and $400 \mathrm{~g} / \mathrm{kg}$ concentrate). The results of the present study also concur with those of the study of Schröder and Südekum ${ }^{(26)}$, who reported that fibre digestion was increased in low-starch diets when glycerol was included at a concentration of $150 \mathrm{~g} / \mathrm{kg}$ DM. In another study, increasing concentrations of glycerol $(0-400 \mathrm{~g} / \mathrm{kg}$ diet $\mathrm{DM})$ have been shown to not affect the in vitro degradability of NDF when added to lucerne hay ${ }^{(27)}$. However, reductions in fibre digestion when glycerol is added to starch-containing diets in vivo ${ }^{(26)}$ and in vitro ${ }^{(28)}$ have been reported. These results have been associated with the inhibition of hemicellulolytic and cellulolytic bacteria ${ }^{(28)}$ and fungi ${ }^{(29)}$. Increased crude protein digestibility from silage is in contrast with the findings of previous studies, which have reported unaffected digestibility of total tract proteins in dairy cows fed glycerol $^{(30)}$ or decreased in sacco degradability of proteins in steers ${ }^{(25)}$. Discrepancies among studies on the effects of glycerol on fibre and protein digestibility are difficult to explain. It is possible that some proteolytic and fibrolytic species may have responded differently to glycerol in the present study, but this is difficult to ascertain as microbial populations were not determined. The quantification of organisms would be important to resolve contradictory results of the effects of glycerol on fibre digestion.

Previous studies have consistently reported a decreased molar proportion of acetate and increases in the proportion of propionate in in vitro conditions using glycerol in starch-rich $^{(9,10)}$ and forage substrates ${ }^{(10,27)}$, as well as in vivo in finishing beef cattle fed concentrate diets ${ }^{(3,26)}$ and in transition dairy cows ${ }^{(31)}$. This concurs with the results of the present study and confirms the propiogenic properties of glycerol. Shifts towards reduced acetate:propionate ratio derived from the increased concentrations of propionate and increases in the concentrations of butyrate have also been reported

Table 3. Effects of increasing concentrations of glycerol on the fermentation characteristics of a brome hay-maize silage diet in the rumen simulation technique

(Mean values with their standard errors)

\begin{tabular}{|c|c|c|c|c|c|c|c|c|}
\hline & \multicolumn{4}{|c|}{ Glycerol* $(g / k g)$} & \multirow[b]{2}{*}{ SEM } & \multicolumn{3}{|c|}{$P$} \\
\hline & 0 & 50 & 100 & 150 & & Linear & Quadratic & Cubic \\
\hline \multicolumn{9}{|l|}{ VFA production $(\mathrm{mmol} / \mathrm{d})$} \\
\hline Total & $18 \cdot 6$ & $19 \cdot 2$ & $20 \cdot 8$ & $25 \cdot 5$ & 1.02 & $<0.001$ & 0.045 & NS \\
\hline Acetate & $10 \cdot 2$ & $9 \cdot 2$ & $8 \cdot 8$ & $10 \cdot 6$ & 0.56 & NS & 0.023 & NS \\
\hline Propionate & $4 \cdot 2$ & 4.9 & $6 \cdot 3$ & 8.4 & 0.57 & $<0.001$ & NS & NS \\
\hline Butyrate & $2 \cdot 7$ & $3 \cdot 1$ & 3.4 & $4 \cdot 1$ & 0.21 & $<0.001$ & NS & NS \\
\hline Valerate & 1.0 & 1.5 & 1.8 & 1.9 & $0 \cdot 11$ & $<0.001$ & $0 \cdot 102$ & NS \\
\hline Caproate & 0.11 & $0 \cdot 14$ & 0.15 & $0 \cdot 13$ & 0.001 & 0.041 & 0.013 & NS \\
\hline Acetate:propionate ratio & $2 \cdot 6$ & 1.9 & 1.4 & 1.3 & 0.05 & $<0.001$ & $<0.001$ & NS \\
\hline $\mathrm{NH}_{3}-\mathrm{N}(\mathrm{mmol} / \mathrm{d})$ & $7 \cdot 0$ & $6 \cdot 9$ & $6 \cdot 5$ & $6 \cdot 5$ & $0 \cdot 12$ & $<0.001$ & NS & NS \\
\hline $\mathrm{pH}$ & $7 \cdot 11$ & $7 \cdot 10$ & 7.09 & 7.07 & 0.011 & 0.035 & NS & NS \\
\hline
\end{tabular}

VFA, volatile fatty acids.

*Experimental substrates: $0=8.5 \mathrm{~g}$ brome hay $+1.5 \mathrm{~g}$ maize silage; $50=8.5 \mathrm{~g}$ brome hay $+1.0 \mathrm{~g}$ maize silage $+0.5 \mathrm{~g}$ glycerol; $100=8.5 \mathrm{~g}$ hay $+0.5 \mathrm{~g}$ maize silage $+1.0 \mathrm{~g}$ glycerol; $150=8.5 \mathrm{~g}$ hay $+1.5 \mathrm{~g}$ glycerol. 
Table 4. Effects of increasing concentrations of glycerol on cumulative gas production and methane production in the rumen simulation technique

(Mean values with their standard errors)

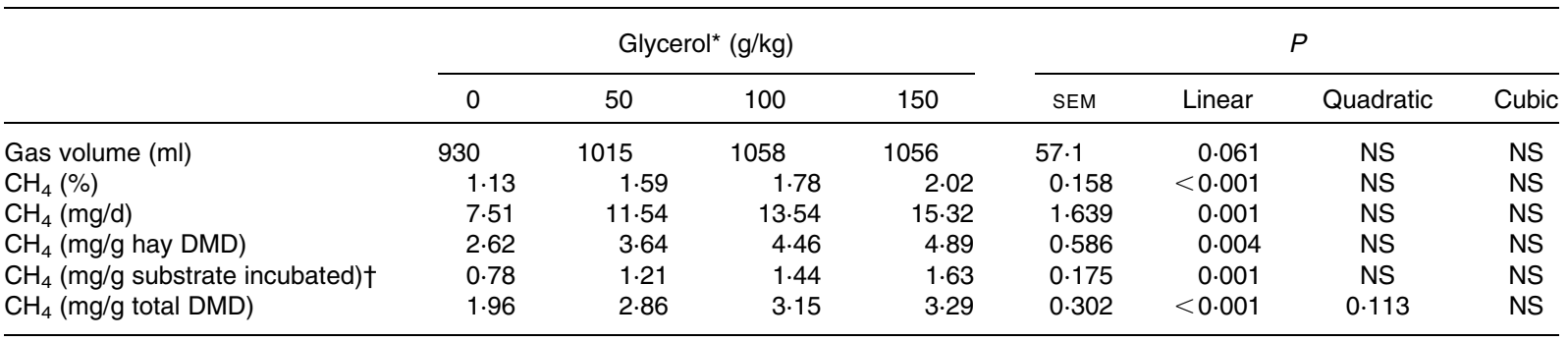

DMD, DM disappeared.

*Experimental substrates: $0=8.5 \mathrm{~g}$ brome hay $+1.5 \mathrm{~g}$ maize silage; $50=8.5 \mathrm{~g}$ brome hay $+1.0 \mathrm{~g}$ maize silage $+0.5 \mathrm{~g}$ glycerol; $100=8.5 \mathrm{~g}$ hay $+0.5 \mathrm{~g}$ maize silage $+1.0 \mathrm{~g}$ glycerol; $150=8.5 \mathrm{~g}$ hay $+1.5 \mathrm{~g}$ glycerol. †DM basis.

in vitro using starch substrates ${ }^{(9)}$ and in vivo using starch- and forage-based diets ${ }^{(26)}$.

The linear increase in $\mathrm{CH}_{4}$ proportion in total gas and total $\mathrm{CH}_{4}$ production as a function of total DM disappeared contradicts our hypothesis. The fermentation of carbohydrates to propionate has been described as a hydrogen sink, and feeding propiogenic substrates has been proposed as a $\mathrm{CH}_{4}$ abatement strategy ${ }^{(11-13)}$. However, glycerol is a more reduced substrate than sugars and releases two electron pairs for each mole of glycerol converted to pyruvate ${ }^{(32)}$, one in the oxidation of glycerol to dihydroxyacetone, which is then phosphorylated and enters glycolysis, and the other in glycolysis itself, in the oxidation of 3-phosphoglyceraldehyde to 3-phosphoglycerate ${ }^{(33)}$. This compensates for electron incorporation in the conversion of pyruvate or phosphoenolpyruvate to propionate. Thus, there is no net electron incorporation in the conversion of glycerol to propionate:

$$
\mathrm{CH}_{2} \mathrm{OHCHOHCH}{ }_{2} \mathrm{OH} \rightarrow \mathrm{CH}_{3} \mathrm{CH}_{2} \mathrm{COOH}+\mathrm{H}_{2} \mathrm{O}
$$

Glycerol failed to decrease $\mathrm{CH}_{4}$ production as hypothesised, but increased it. There was an increase in butyrate production as glycerol replaced maize silage. Butyrate production from both carbohydrates and glycerol would result in a release of reducing equivalents and contribute to increasing $\mathrm{CH}_{4}$ production:

$$
\mathrm{CH}_{2} \mathrm{OHCHOHCH}{ }_{2} \mathrm{OH} \rightarrow \frac{1}{2} \mathrm{CH}_{3} \mathrm{CH}_{2} \mathrm{CH}_{2} \mathrm{COOH}+\mathrm{CO}_{2}+2[2 \mathrm{H}] .
$$

Less amounts of glycerol seem to be fermented to acetate ${ }^{(34)}$. Acetate production was quadratically affected by the substitution of maize silage with glycerol, but changes were of relatively low magnitude. Glycerol stimulated DM disappearance, but because glycerol replaced maize silage, the amounts of total forage digested DM were actually lower as there were less amounts of maize silage to be digested and less amounts of carbohydrates were fermented. Therefore, changes in acetate production seem to have resulted from a shift in carbohydrate fermentation towards acetate, which would also release reducing equivalents and contribute to the increase in $\mathrm{CH}_{4}$ production, because the increase in propionate production from glycerol would not demand extra reducing equivalents. The formation of some butyrate and acetate from glycerol instead of from carbohydrates would further contribute to the enhancement of methanogenesis, again because being more reduced than carbohydrates, glycerol would result in a greater release of reducing equivalents per mol of acetate and butyrate produced compared with carbohydrates.

An alternative explanation for the increase in $\mathrm{CH}_{4}$ production with glycerol is based on the equimolar conversion of glycerol to formate and ethanol by an isolate from deer rumen identified as Klebsiella planticola ${ }^{(35)}$. Formate is a precursor of $\mathrm{CH}_{4}{ }^{(36)}$, and large amounts of ethanol are oxidised to acetate in the rumen ${ }^{(37,38)}$, a process that releases reducing equivalents that can be used for $\mathrm{CH}_{4}$ production ${ }^{(39)}$. It has been shown that pure cultures of Ruminococcus flavefaciens ${ }^{(40)}$, R. albus ${ }^{(41)}$ and a ruminal fungus ${ }^{(42)}$ decrease formate and ethanol production when co-cultured with methanogens, as $\mathrm{CH}_{4}$ becomes the main electron sink in the co-cultures. Also, some microorganisms can convert glycerol to 1,2-propanediol ${ }^{(43)}$, and in turn there is some recovery of $1{ }^{14} \mathrm{C}-1,2$-propanediol incubated in ruminal continuous cultures as ${ }^{14} \mathrm{CH}_{4}{ }^{(44)}$.

The adaptation of donor animals to diets containing glycerol seems to have affected fermentation when glycerol was included in in vitro batch culture incubations. Gas and $\mathrm{CH}_{4}$ production was increased when $150 \mathrm{~g} / \mathrm{kg}$ glycerol was included in the substrates $(900 \mathrm{~g} / \mathrm{kg}$ concentrate based on rolled maize, maize gluten feed and soyabean hulls) using inoculum obtained from glycerol-adapted animals ${ }^{(45)}$, but changes in $\mathrm{CH}_{4}$ production were negligible when the inoculum was obtained from unadapted animals, suggesting that microbial adaptation influences digestion and fermentation end products. This explains, at least partially, the differences between previous studies reporting no effect ${ }^{(10)}$ or decreased $\mathrm{CH}_{4}$ production ${ }^{(14)}$ when incubating glycerol in in vitro batch cultures using inoculum obtained from unadapted animals as opposed to the results of the present study, where increased propionate and total VFA production and linear increase in DM loss were found to be associated with increased $\mathrm{CH}_{4}$ production $(\mathrm{mg} \mathrm{CH} / \mathrm{g} \mathrm{DM}$ digested) using glycerol-adapted fermenters. When increasing 
concentrations of glycerol were fed to adapted lambs, no effects on $\mathrm{CH}_{4}$ emissions were observed ${ }^{(4)}$. In this case, absorption through the rumen wall or passage to the lower gut or both may have impeded fermentation of an important proportion of glycerol $^{(7)}$, thus reducing the release of hydrogen electrons in the rumen environment when compared with in vitro fermenters where absorption is precluded.

\section{Conclusions}

Increasing concentrations of glycerol in forage diets incubated in a RUSITEC apparatus improved DM, NDF and ADF disappearance from brome hay and maize silage and crude protein disappearance from maize silage. The acetate:propionate ratio was linearly decreased as a result of increased production of propionate. The concentrations of $\mathrm{CH}_{4}$ in gas and total $\mathrm{CH}_{4}$ production per unit of DM digested or incubated were increased, as the fermentation of glycerol to propionate does not act as a hydrogen sink.

\section{Acknowledgements}

The present study was supported by Canada-Norway Greenhouse Gas Project and the SAGES programme of Agriculture and Agri-Food Canada. J. A.-S. is supported by a ConicytChile Scholarship. The funding agencies had no role in the design and analysis of the study or in the writing of this article.

The authors' contributions were as follows: J. A.-S., A. V. C. and T. A. M. designed the study; J. A.-S. and G. d. O. R. conducted the experimental procedures and laboratory analyses; J. A.-S. and A. V. C. analysed and interpreted the data; J. A.-S. wrote the first draft of the manuscript; A. V. C., T. A. M., E. M. U. and G. d. O. R. critically revised the manuscript.

The authors declare that there is no conflict of interest with any financial organisation regarding the material discussed in the manuscript.

\section{References}

1. Chung YH, Rico DE, Martinez CM, et al. (2007) Effects of feeding dry glycerin to early postpartum Holstein dairy cows on lactational performance and metabolic profiles. J Dairy Sci 90, 5682-5691.

2. Parsons GL, Shelor MK \& Drouillard JS (2009) Performance and carcass traits of finishing heifers fed crude glycerin. J Anim Sci 87, 653-657.

3. Mach N, Bach A \& Devant M (2009) Effects of crude glycerin supplementation on performance and meat quality of Holstein bulls fed high-concentrate diets. J Anim Sci 87, 632-638.

4. Avila-Stagno J, Chaves AV, He ML, et al. (2012) Effects of increasing concentrations of glycerol in concentrate diets on nutrient digestibility, methane emissions, growth, fatty acid profiles and carcass traits of lambs. J Anim Sci 91, 829-837.

5. Gunn PJ, Schultz SL, Van Emon ML, et al. (2010) Effects of elevated crude glycerin concentrations on feedlot performance, carcass characteristics, and serum metabolite and hormone concentrations in finishing ewe and wether lambs. Prof Anim Sci 26, 298-306.

6. Musselman AF, Van Emon ML, Gunn PJ, et al. (2008) Effects of crude glycerin on feedlot performance and carcass characteristics of market lambs. Am Soc Anim Sci West Sect Proc 59, 353-355.

7. Rémond B, Souday E \& Jouany JP (1993) In vitro and in vivo fermentation of glycerol by rumen microbes. Anim Feed Sci Technol 41, 121-132.

8. Johns AT (1953) Fermentation of glycerol in the rumen of sheep. N Z J Sci Technol 35, 262-269.

9. Bergner H, Kijora C, Ceresnakova Z, et al. (1995) In vitro studies on glycerol transformation by rumen microorganisms. Arch Tierernahr 48, 245-256.

10. Avila JS, Chaves AV, Hernandez LM, et al. (2001) Effects of replacing barley grain in feedlot diets with increasing levels of glycerol on in vitro fermentation and methane production. Anim Feed Sci Technol 166-167, 265-268.

11. Boadi D, Benchaar C, Chiquette J, et al. (2004) Mitigation strategies to reduce enteric methane emissions from dairy cows: update review. Can J Anim Sci 84, 319-335.

12. Beauchemin KA, Kreuzer M, O'Mara F, et al. (2008) Nutritional management for enteric methane abatement: a review. Aust J Exp Agric 48, 21-27.

13. McAllister TA \& Newbold CJ (2008) Redirecting rumen fermentation to reduce methanogenesis. Aust J Exp Agric 48, 7-13.

14. Lee SY, Lee SM, Cho YB, et al. (2011) Glycerol as a feed supplement for ruminants: in vitro fermentation characteristics and methane production. Anim Feed Sci Technol 166-167, 269-274.

15. Kijora C, Bergner H, Gotz KP, et al. (1998) Research note: investigation on the metabolism of glycerol in the rumen of bulls. Arch Tierernahr 51, 341-348.

16. Beauchemin KA, Janzen HH, Little SM, et al. (2010) Lifecycle assessment of greenhouse gas emissions from beef production in western Canada: a case study. Agric Syst 103, 371-379.

17. Canadian Council on Animal Care (1993) Guide to the Care and Use of Experimental Animals [ED Olfert, BM Cross and AA McWilliams, editors]. 2nd ed. vol. 1. Ottawa, ON: Canadian Council on Animal Care.

18. Czerkawski JW \& Breckenridge G (1977) Design and development of a long term rumen simulation technique (Rusitec). BrJ Nutr 38, 371-384.

19. Fraser GR, Chaves AV, Wang Y, et al. (2007) Assessment of the effects of cinnamon leaf oil on rumen microbial fermentation using two continuous culture systems. J Dairy Sci 90, 2315-2328.

20. Soliva CR, Kreuzer M, Foidl N, et al. (2005) Feeding value of whole and extracted Moringa oleifera leaves for ruminants and their effects on ruminal fermentation in vitro. Anim Feed Sci Technol 118, 47-62.

21. Association of Official Analytical Chemists (2006) Official Methods of Analysis, 18th ed. Arlington, VA: AOAC.

22. Van Soest PJ, Robertson JB \& Lewis BA (1991) Methods for dietary fibre, neutral detergent fibre, and non-starch polysaccharides in relation to animal nutrition. J Dairy Sci $\mathbf{7 4}$, 3583-3597.

23. Wang Y, McAllister TA, Rode LM, et al. (2001) Effects of an exogenous enzyme preparation on microbial protein synthesis, enzyme activity and attachment to feed in the Rumen Simulation Technique (Rusitec). Br J Nutr 85, 325-332. 
24. Rhine ED, Sims GK, Mulvaney RL, et al. (1998) Improving the Berthelot reaction for determining ammonium in soil extracts and water. Soil Sci Soc Am J 62, 473-480.

25. Wang C, Lui Q, Huo WJ, et al. (2009) Effects of feeding glycerol on rumen fermentation, urinary excretion of purine derivatives and feed digestibility in steers. Livest Sci 121, 15-20.

26. Schröder A \& Südekum KH (1999) Glycerol as a by-product of biodiesel production in diets for ruminants. In New Horizons for an Old Crop. Proceedings of 10th International Rapeseed Congress. Paper no. 241 [N Wratten and PA Salisbury, editors]. Gosford, NSW: The Regional Institute Ltd.

27. Krueger NA, Anderson RC, Tedeschi LO, et al. (2010) Evaluation of feeding glycerol on free-fatty acid production and fermentation kinetics of mixed ruminal microbes in vitro. Bioresour Technol 101, 8469-8472.

28. Abo El-Nor S, Abu Ghazaleh AA, Potu RB, et al. (2010) Effects of differing levels of glycerol on rumen fermentation and bacteria. Anim Feed Sci Technol 162, 99-105.

29. Roger V, Fonty G, Andre C, et al. (1992) Effects of glycerol on the growth, adhesion, and cellulolytic activity of rumen cellulolytic bacteria and anaerobic fungi. Curr Microbiol 25, 197-201.

30. Rico DE, Chung YH, Martinez CM, et al. (2012) Effects of partially replacing dietary starch with dry glycerol in a lactating cow diet on ruminal fermentation during continuous culture. J Dairy Sci 95, 3310-3317.

31. DeFrain JM, Hippen AR, Kalscheur KF, et al. (2004) Feeding glycerol to transition dairy cows: effects on blood metabolites and lactation performance. J Dairy Sci 87, 4195-4206.

32. Zhang A \& Yang ST (2009) Propionic acid production from glycerol by metabolically engineered Propionibacterium acidipropionici. Process Biochem 44, 1346-1351.

33. Biebl H, Menzel K, Zeng A-P, et al. (1999) Microbial production of 1,3-propanediol. Appl Microbiol Biotechnol 52 , 289-297.

34. Czerkawski JW \& Breckenridge G (1972) Fermentation of various glycolytic intermediates and other compounds by rumen micro-organisms, with particular reference to methane production. Br J Nutr 27, 131-146.

35. Jarvis GN, Moore ERB \& Thiele JH (1997) Formate and ethanol are the major products of glycerol fermentation by a Klebsiella planticola strain isolated from red deer. J Appl Microbiol 83, 166-174.

36. Hungate RE, Smith W, Bauchop T, et al. (1970) Formate as an intermediate in the bovine rumen fermentation. J Bacteriol 102, 389-397.

37. Pradhan K \& Hemken RW (1970) Utilization of ethanol and its effect on fatty acid patterns in ruminants. J Dairy Sci 53, 1739-1746.

38. Jean-Blain C, Durix A \& Tranchant B (1992) Kinetics of ethanol metabolism in sheep. Reprod Nutr Dev 32, 83-90.

39. Moomaw CR \& Hungate RE (1963) Ethanol conversion in the bovine rumen. J Bacteriol 85, 721-722.

40. Latham MJ \& Wolin MJ (1977) Fermentation of cellulose by Ruminococcus flavefaciens in the presence and absence of Methanobacterium ruminantium. Appl Environ Microbiol 34, 297-301.

41. Pavlostathis SG, Miller TL \& Wolin MJ (1990) Cellulose fermentation by continuous cultures of Ruminococcus albus and Methanobrevibacter smithii. Appl Microbiol Biotechnol 33, 109-116.

42. Bauchop T \& Monfort DO (1981) Cellulose fermentation by a rumen anaerobic fungus in both the absence and the presence of rumen methanogens. Appl Environ Microbiol 34, 297-301.

43. Clomburg JM \& Gonzalez R (2013) Anaerobic fermentation of glycerol: a platform for renewable fuels and chemicals. Trends Biotechnol 31, 20-28.

44. Czerkawski JW, Piatkova M \& Brekenridge G (1984) Microbial metabolism of 1,2-propanedioI studied by the Rumen Simulation Technique (Rusitec). J Appl Bacteriol 56, 81-94.

45. van Cleef EH, Uwituze S \& Drouillard JS (2011) Effects of crude glycerin on in vitro gas production, dry matter disappearance, VFA profiles, and composition of fermentative gasses. J Anim Sci 89, E-Suppl. 1, 613. 